\title{
Analysis of the Legal and Institution-Building Experiences Related to the Supervision of Dangerous Shipment
}

\author{
KÁTAI-URBÁN Lajos ${ }^{1}$
}

\begin{abstract}
The development of the Hungarian system for industrial safety has a history of 15 years. The aim of this article is to overview the measures related to the develop-ment of the legislative area for industrial safety in the field of dangerous goods transportation and draw upon the potential experiences of this progress. Keywords: industrial safety; transport accidents; transportation of dangerous goods; disaster management.
\end{abstract}

\section{Introduction - a Historical Overview}

Hungary's geographical location is rather favourable, it plays an important role in the trans- portation to and from countries in the East and South. Transportation of a significant amount of dangerous goods takes place mainly by road, by rail, and increasingly by manageable waterways and by air.

International European Union legislation on the various modes of transportation are ad- opted into the legal system of Hungary. Around the turn of the millennium, EU legislation based on the international agreements on the transportation of dangerous goods (adminis- tered by UN European Economic Commission) were adapted in the national legal system. [1] Even when the first disaster management act came into force in 2000, the prevention of transport accidents involving dangerous goods together with the quick and profession- al response to them in order to protect the citizens and the environment were considered significant tasks. Professional bodies of disaster management paid special attention to the constant development of human and technical conditions of prevention, preparedness and responses. [2]

The need for traffic safety and decreasing environmental impact despite the growing vol- ume of dangerous goods transport is a justified social need. Therefore, regular and consistent inspections of related establishments, investigation of incidents as well as penalties for defi- ciencies and failures have become the main preventive tasks of the authorities.

Following the 2001 modification of the decree on the designation of the route of vehicles transporting dangerous goods by road, [3] disaster management bodies have been involved in the authority checks of dangerous goods transport by road. By adapting the EU legislation coming into force in 2002, the professional bodies of disaster management in cooperation with the supervisory authorities were provided with the power to check dangerous goods transport by road and the related establishments. In 2004 - after assessing 3 years of experi-

1 National University of Public Service; Institute for Disaster Management, e-mail: katai.lajos@uni-nke.hu 
ence - the need emerged to extend the power to check, which already included independent inspections and penalties as well. Disaster management requested for an extended power to check other modes of transport as well.

Disaster management has taken substantial steps to establish authority and enforcement institutions, to create the necessary human and technical conditions and to ensure unitary and effective application of law. Internal procedures, methodological guides and databases were created. Instruments of checks were developed. The personnel underwent training.

After its proposals for law modifications were approved, disaster management gained independent right to check and fine on $1^{\text {st }}$ May, 2007. Development of this field gained mo- mentum between 2007-2009, greatly supported by the income from penalties. By the end of

2009, disaster management had become a decisive element of checks on road transport of dangerous goods, recognised by other cooperating authorities. Extensive professional expe- rience accumulated and excellent working relations were established with the partner author- ities, consultant and interest organisations.

After the income from penalties came to a halt in 2010, the volume of checks slightly decreased until in 2011 it started to continue steadily. A system of cooperation between in- spection authorities was established, coordinated by the transport authority. A crucial element of the development concept of disaster management was the extension of the right to check and fine dangerous goods transport by road to all modes of transport as part of industrial safety. By the end of 2011, the legislation was approved, the institution system of industrial safety was created, and the methodological, human and technical conditions were available.

After $1^{\text {st }}$ January 2012, with the second disaster management act coming into force, the modifications in the acts on transport and the new inspection regulation created the legal background for disaster management to act as an independent authority in the following activities: check dangerous goods transported by rail, inland waterway and air, impose fines, investigate incidents and take measures to prevent emergencies.

Dangerous goods transported by rail and inland waterway have been checked by disaster management since 2012 , while air transport since 2015. Keeping track of dangerous consign- ments is realised through the introduction of notification obligation.

The goal of this paper is to present a brief historical overview and a professional analysis on the legal changes regarding the disaster management supervision on dangerous goods transport, as well as the steady strengthening of the institution system. The experience related to the introduction of the implementing measures on the power of check and fine dangerous goods transport will be detailed in another paper.

\section{Assessment of the Risks of Dangerous Shipments in Hungary}

Dangerous goods transport is attracting more and more attention from the decision makers both in Hungary and in the European Union. Thus, the prevention of transport accidents involving dangerous goods and quick and professional response to them have emerged as a new challenge in order to protect the citizens and the environment. According to the fig- ures of Ministry of the Interior National Directorate General for Disaster Management (MoI NDGDM), in 2012, in Hungary the volume of goods transported by road was 20 million tonne-kilometres, by rail 10 million tonnekilometres, while by air 300-400 flights a year. [4] 
Regarding the destination of the goods, we can differentiate between domestic and inter- national transportation. Dangerous goods are present in road traffic (transported by road), on the railways, at freight stations, at border inspection posts, at railway facilities (transported by rail), on national and international waterways, at ports, at berths (transported by water- ways) and at other related premises. When transported by air, dangerous goods are present in facilities where they are prepared for the flight.

Dangerous goods account for 19-20\% of goods transported by rail. Compared to road transport, its great advantage is being more economical when goods are transported in bigger quantities for longer distances, while weather conditions and traffic risks do not have such a major influence as road transport. One of the crucial points of the EU railway policy is the gradual shift from road to railway transport because of environmental reasons. The majority of goods transported by rail are flammable liquids and gases and corrosive materials.

Experts' opinions differ on whether road or rail transport poses higher vulnerability on the local population. Rail transport is preferred on longer distances (over $200 \mathrm{~km}$ ), whereas by road the transportation of the following materials is significant: flammable liquids and gases in tanks, pyrotechnic articles, medical waste, hazardous waste, industrial and LPG cylinders. Transportation of radioactive materials cannot be neglected either because of the special care they require. [5]

Transportation of highly flammable liquids accounts for the bulk of inland waterway transport.

Premises and establishments related to the transportation of dangerous goods can be di- vided into the following five groups in line with the methods of transport: road transport establishments; rail transport establishments; inland waterway transport establishments; air transport establishments; pipeline transportation establishments. [6]

Road transport establishments include warehouses storing dangerous goods in $\mathrm{ADR}^{2}$ packages. Warehouses of major logistics importance can all be found in the agglomeration of Budapest. From this area any part of the country can be reached within 2-3 hours. Some of the warehouses require a licence of industrial safety, except combi terminals handling containers. Currently, there are 6 upper tier and 5 lower tier dangerous establishments in Hungary. [7]

Rail transport establishments are primarily the marshalling yards, which do not belong in dangerous establishments. According to the information of MoI NDGDM, altogether 14 stations were identified by MÁV (Hungarian State Railways) Ltd., the most important ones being in Ferencváros, Miskolc, Szolnok and Záhony. The other major type of rail transport establishments is the marshalling yards and rail sidings of establishments producing, pro- cessing and storing hazardous materials. Marshalling yards and rail sidings in the vicinity of dangerous establishments or below tier establishments pose a high risk. Rail sidings present a unique and considerable danger, as a great number of wagons are present without any phys- ical protection or industrial safety supervision.

Road-rail intermodal terminals are either dangerous establishments or non-classified plants. When the containers are transferred, it is a common problem that safety is dependent

2 Formally, the European Agreement Concerning the International Carriage of Dangerous Goods by Road; is a United Nations treaty (1957) that governs transnational transport of hazardous materials. The abridgement ADR derived from the French name for the treaty: Accord européen relatif au transport international des marchandises $D$ angereuses par Route. 
on the changing attitude of the foreign or Hungarian senders and the mechanical condition of the containers and the railway wagons.

Inland waterway establishments include loading and unloading establishments and ports handling dangerous goods.

As regards air transportation, dangerous goods warehouses on the territory or in the vicin- ity of the airports are considered by the disaster management authority, which do not present a major threat - compared with other methods of transport - given the relatively small quan- tity of goods.

Pipeline transportation establishments are subject to the legislation on the protection against major incidents involving hazardous materials.

The transportation of hazardous waste is given special attention from the viewpoint of dangerous goods transportation. In Hungary 4 hazardous waste disposal sites and 9 waste incineration plants are identified. [8]

Loading and unloading hazardous materials onto vehicles may be included among the dangerous activities, given the risk of spills. Vehicles transporting dangerous goods may stop or park in the vicinity of residential and frequented areas, which increases vulnerability. Damaged packaging may result in a release into the environment, which may happen by acci- dent, but intentional acts cannot be excluded either. Serious risk is presented by any accidents that may occur during the transportation of dangerous goods. Equipment necessary for the response might not be readily available at the site, which leads to increased vulnerability of the environment. [9]

\section{Development of the Legal Regulations on Dangerous Goods Transport}

Special safety conditions of dangerous goods transport are laid down in the Hungarian leg- islation. Interstate (international) agreements bind us to observe them in international trans- port. The international standards are strict, yet very up-to-date. Rail, road, inland waterway (not sea) as well as sea and air transport have their own regulations regarding the transport of dangerous goods. Legislation adopted by the EU member states are based on international legislation.

The Committee of Experts on the Transport of Dangerous Goods of the United Nations Economic and Social Council (ECOSOC) sets the safety requirements for the transportation of the most common dangerous materials by every mode of transport. The requirements are updated and published every two years under the title of Recommendations on the Transport of Dangerous Goods - Model Regulations, also called as Orange Book. [10]

The first issue, published in 1957, included the criteria for identifying dangerous goods, packaging, labelling and accompanying documents. The UN Recommendations are not le-gally binding, but they provide a basis to develop requirements specific to the modes of transport. The UN Recommendations consist of two volumes: model regulations and criteria for tests.

The Committee of Experts recommends the up-to-date safety requirements for the gov- ernments and international organisations in charge of regulating the various modes of trans- port. These organisations are the following: United Nations Economic Commission for Eu- rope (UN ECE) in road and inland waterway transport, Intergovernmental Organisation for 
International Carriage by Rail (OTIF) in rail transport, International Maritime Organisation (IMO) in sea transport, and International Civil Aviation Organization (ICAO) in air transport.

International agreements on the transportation of dangerous goods have been concluded on each mode of transport on the basis of the UN recommendations:

- The European Agreement concerning the International Carriage of Dangerous Goods by Road (ADR) was done on 30 September, 1957, in Geneva, reviewed every two years. Hungary joined the agreement in 1979.

- Regulation concerning International Carriage by Rail (RID), appearing as Appendix C of the Convention concerning International Carriage by Rail (COTIF), was signed on 3 June 1999 in Vilnius, modified later. Its counterpart in Eastern-Europe is the Agreement on International Freight Transportation by Railways, currently in effect.

- Carriage of Dangerous Goods by Inland Waterways (ADN) was concluded on $26^{\text {th }}$ May, 2000, in Geneva, modified later.

- Annex 18 of the Convention on International Civil Aviation is the Technical Instruc- tions for the Safe Transport of Dangerous Goods by Air (ICAO TI). The agreement was proclaimed in Hungary by the Legislative Decree 25 of 1971, while the annexes by the Decree 20/1997. (X. 21.) of the Minister of Water, Transport and Communications. International Air Transport Association Dangerous Goods Regulations (IATA DGR) is widely used by airlines.

- International Maritime Dangerous Goods Code (IMDG Code) is in Chapter VII, Part A of the international agreement called International Convention for the Safety of Life at Sea (SOLAS). [11]

Based on legal experiences, in order to deal with practical difficulties encountered, legis- lation is repeatedly reviewed and periodically (usually every two years) modified in line with technical committee recommendations.

Directive 2008/68/EC of the European Parliament and of the Council on the inland trans- port of dangerous goods is adopted regarding the transport of dangerous goods by road, rail and inland waterway. Directive 95/50/EC on uniform procedures for checks on the transport of dangerous goods by road sets out requirements for the checks on road transport of dan- gerous goods.

National legislation is based on the adaptation of the regulations on the checks laid down in international agreements, in line with EU requirements. The authority's power to check is included in the laws specific to each mode of transport and their implementing regulations.

Between 1990 and 2007 the regulation on the designation of dangerous goods routes were applied, which made it possible for the affected authorities to monitor the movement of dangerous goods.

In 2005 public safety measures were added to the international agreements on the trans- port of dangerous goods (Chapter 1.10 of ADR, RID and ADN). Companies producing, dispatching, delivering or storing dangerous goods along with other participants of the transportation - present a considerable risk to public safety, so they are obliged to prepare a security plan.

In line with the Ministry of National Development Decree 25/2014. (IV. 30.) on the safety advisor for the transport of dangerous goods, heads of companies engaged in the transport of dangerous goods by road, rail or inland waterway are entitled to appoint a minimum of one safety advisor in writing. 
According to the road transport law, the transport authority, police, disaster management and customs authorities are entitled to check and impose fines regarding the transport of dangerous goods, the carrier, the road vehicle and its crew, the dispatcher of the goods, the temporary storage, the packager, the loader, the recipient and the appointment and qualifica- tion of the safety advisor.

The decree on the uniform procedures for checks on the transport of dangerous goods by road, coming into effect on $1^{\text {st }}$ March, 2002, is considered a basic implementing regulation. In disaster management, its local authority is entitled to conduct checks. The local authority of disaster management may conduct independent checks on the area of another disaster management authority, with the prior consent of the central organ of the disaster management authority.

The checklist for inspections is specified in the annex to the decree. The authority may take samples of goods for laboratory examination. In the case of infringement, the authority imposes sanctions and immobilizes the vehicle, in line with a separate decree of fine.

The Act of 2011 concerning disaster management and amending certain related acts (Di- saster Management Act), by modifying the laws on transport, created the legal background for disaster management to carry out independent checks on the transport of dangerous goods by rail, inland waterway and air as well, together with imposing fines and inspecting ac- cidents. The implementing decree of transport laws was introduced in 2011 as well. [12] Companies involved in rail transport are subject to notification requirement to disaster man- agement concerning their transport activities.

Based on the act on air transport, the implementing decree concerning the air transport of dangerous goods entered into force on $1^{\text {st }}$ January, 2015. It covers the rules of authority checks and fines imposed by disaster management, empowering it with the licence to check, fine and to carry out on-the-spot actions related to air transport.

The local or regional bodies of disaster management may carry out independent checks on air transport of dangerous goods. The checks can be performed by them on the area of other disaster management authorities as well, with the consent of the central organ of disas- ter management.

Inbound dangerous goods shipment must be reported in writing to the regional body of di- saster management by the handling personnel within three hours after the arrival. Dangerous goods to be dispatched must be reported by either the sender or the handling personnel three hours before forwarding the goods.

Inspection of incidents involving the transport of dangerous goods as well as assessing the related experience are of utmost importance. Inspection of incidents involving the trans- port of dangerous goods are primarily performed by disaster management mobile laborato- ries (DMML).

\section{Constant Analysis of the Results of Institutional Development}

The Department for Industrial Accident Response (DIAR - National Centre for Industrial Accident Prevention), subordinated to the MoI NDGDM founded on $1^{\text {st }}$ January, 2000, was in charge of the tasks related to the establishment of the legal system, institution system, pro- cedures and set of instruments connected to dangerous goods transport in Hungary. 
County and capital directorates of disaster management (altogether 20) employed desk officers dealing with dangerous goods transport, who were in charge of organising and per- forming inspections and fines. Civil protection branch offices of local disaster management bodies were also involved in checks. Desk officers and employees appointed to conduct checks (2-5 persons/directorate) took courses run by MoI NDGDM, which qualified them as administrators for dangerous goods transport. Specialists from MoI NDGDM and regional bodies gained qualifications as safety advisors for the transport of dangerous goods. Desk officers took part in regular trainings and workshops once or twice a year in Balatonföldvár. Moreover, supervisors had to participate in centrally organised regional trainings - in re- sponse to the changing regulations.

Procedures for checks and fines were described in the internal regulations (provisions) of MoI NDGDM and regional bodies, modified every 2-3 years. Methodological guides on checks were annexed to these provisions.

MoI NDGDM provides specialists with several additional materials and publications to facilitate checks.

MoI NDGDM has good relations not only with other authorities, but it also cooperates with the operators' representative bodies.

An autonomous department for industry and transport, the Department for Industrial Accident Response and Supervision was created within MoI NDGDM on $15^{\text {th }}$ September, 2003.

A database was developed by MoI NDGDM, called "Dangerous Goods Transport Infor- mation System", in order to keep record of procedures. "ADR Statinfo" CD contributed to quicker, more simple, accurate and effective checks.

Ensuring the financial and technical conditions for the independent checks was a constant issue until the incomes from fines became available.

Annual reports were made and also published online on the activities of the disaster man- agement authority until 2011. Since 2010, annual check plans were developed, coordinated by the National Transport Authority (NTA). The methodological guide for the authorities performing checks are based on the check manual of MoI NDGDM.

The relevant department was named the Department for Industrial Safety in 2010. In

2012, once the National Inspectorate General for Industrial Safety came into being, the Department for Dangerous Goods was established.

Within the structure of MoI NDGDM, the National Inspectorate General for Industrial Safety is subordinated to the Deputy General. Each field of speciality is controlled by the relevant department. At the regional level, the Disaster Management Authority Departments (20) are integrated into the capital and county disaster manager directorates, subordinated to the deputy director. They act in the first and second instance in official matters. Capital and county inspectorate generals for industrial safety are also present at the regional level. At the local level, disaster management authority departments of the Disaster Management Branch Offices (65) act in the first instance. At each Branch Office, an inspectorate is responsible for performing and coordinating tasks related to industrial safety. [13]

The regulation coming into effect in 2012 was preceded by two years of preparatory work, when the Disaster Management Act and its implementing decrees, together with the acts on road, rail and air transport were formulated thanks to the Department for Industrial Safety. Internal regulations of MoI NDGDM were also drawn up, containing the authority proce- dures and flowcharts, specimen documents and methodological guides. Specialists working 
in disaster management or transport participated in trainings for inspectors of dangerous goods transport to familiarise themselves with the related legislation and internal regulations.

The National Inspectorate General for Industrial Safety, MoI NDGDM receives profes- sional support from the Industrial Safety Advisory Council, MoI NDGDM as well as the In- stitute of Disaster Management (IDM), of the National University of Public Service (NUPS). The IDM of the NUPS was founded on $1^{\text {st }}$ January, 2012. The new disaster management course was launched in the school year of 2013-2014, one of its specialisations being indus- trial safety for full-time and correspondent students. Industrial safety course material was included in the defence administration MSc. Starting from the school year 2016-2017, sub- jects will be available with their curricula focusing on actual industrial safety. At the Doctoral School of Military Engineering of the NUPS industrial safety specialists may launch research topics or subjects. [14] [15]

The courses on dangerous goods transport run by MoI NDGDM cover all modes of trans- port. The training for administrators for dangerous goods transport was launched in 2004, or- ganised by MoI NDGDM. Training for other modes of transport were developed in 2011. The training plans of courses for inspectors of dangerous goods transport held at the Disaster Man- agement Training Centre were based on the syllabus of MoI NDGDM courses. Authorities also employ supervisors qualified as safety advisors for the transport of dangerous goods. [16] Until the end of 2011, regional

Emergency Reconnaissance Teams were responsible for performing inspections on transport accidents involving

dangerous goods. Since 2012, Di- saster Management Mobile Laboratories (DMML), supervised by the National Inspectorate for Industrial Safety, MoI NDGDM, have been responsible for collecting, systematising and analysing data to assess the emergency and for identifying toxic or radioactive materials on the spot. Moreover, if needed, they participate in the coordination of decontamination. [17]

\section{Conclusion}

Regarding the transport of dangerous goods, it can be said that the presence of disaster man- agement authorities in each mode of transport will continue to be a significant task, greatly contributing to increasing transport safety, thus public safety. Check results and also feed- back from the society justify the need for disaster management to continue to act as an inde- pendent authority in checks on dangerous goods transport.

The activities of the disaster management authority connected to checks and fines on road underwent continuous progress between 2001 and 2012 and became a recognised field with- in industrial safety. Its supervision over dangerous establishments and shipments in 2010, demonstrating a high level of expertise, provided a basis for developing a new system of tasks and instruments of industrial safety.

Due to the legislation preparatory work and institutional development between 2010 and 2012, the industrial safety authority became more dynamic and stronger after $1^{\text {st }}$ January,

2012. Since this date, coordinating the activities related to dangerous shipments is incorpo- rated into industrial safety, empowered with more authority. Since early 2015, its activities extend to all modes of transport.

Developing the system of checks and sanctions covering every mode of transport was supported by experience gathered between 2001 and 2012, on legislation preparatory work and law application connected to road transport. 
It can be concluded that the enforcement institutions are effective, and most of the per- sonnel and technical conditions are granted. Industrial safety courses run by the Institute of Disaster Management, NUPS and trainings for inspectors run by the DMTC have become significant. Disaster management has a balanced relationship with partner authorities, inter- est organisations and safety consultant associations. Since 2012 the Safety Advisory Council, MoI NDGDM have been offering professional support to scientific activities, accompanied by the relevant department of IDM of the NUPS.

Currently, in Hungary checks on dangerous goods transport are performed by local bodies of disaster management in the total areas of regional bodies. Checks may be expected in road traffic (road transport), on the railways, at freight stations, at border inspection posts, at rail- way facilities (rail transport), on national and international waterways, at ports, at berths (wa- terway transport) and at other related premises. When transported by air, dangerous goods listen in the legislation can be checked when they are prepared for the flight. Moreover, local and regional bodies of disaster management are also entitled to act as an independent au- thority when checking dangerous goods that arrived by air but nor forwarded directly by air.

Based on the assessment of road accidents, it can be concluded that the major cause of ac- cidents are basically traffic violations or inattention, but occasionally infringements in goods handling also occur. Rail incidents reveal that their primary cause is leaking in loading and unloading fittings as well as the unsatisfactory technical conditions of tank wagons and the lack of their maintenance.

The overall conclusion is that, in accordance with the requirements of the EU, interna- tional organisations and the Hungarian government, the supervision of dangerous shipments in Hungary ensures the protection of human life and health, the environment and material property, thus contributing to public safety in Hungary as set out in the Constitution.

\section{References}

[1] KÁTAI-URBÁN L.: Establishment and Operation of the System for Industrial Safety within the Hungarian Disaster Management. Ecoterra: Journal of Environmental Research and Protection, 112 (2014), 27-45.

[2] KÁTAI-URBÁN L., VASS Gy.: Kézikönyv a veszélyes üzemek biztonságszervezésével kapcsolatos alapfeladatok teljesitéséhez. (Handbook for Implementation of Basic Tasks related to the Safety Management of Dangerous Establishments.) Budapest: Nemzeti Közszolgálati Egyetem, 2014.

[3] Council of Ministers decree No 122/1989. (XII. 5.) on the designation of the route of vehicles transporting dangerous goods by road.

[4] KÁTAI-URBÁN L., VASS Gy.: Kézikönyv: Veszélyes üzemek, tevékenységek és technológiák az iparban. (Dangerous Industrial Establishments, Activities and Technology.) Budapest: Nemzeti Közszolgálati Egyetem, 2014.

[5] HORVÁTH H., KÁTAI-URBÁN L.: Assessment of the Implementation Practice of Emergency Planning Regulations Dedicated to the Rail Transportation of Dangerous Goods. AARMS, 121 (2013), 73-82.

[6] KÁTAI-URBÁN L., KISS E.: Inspection of the Transportation of Dangerous Goods by Inland Waterways in Hungary. AARMS, 132 (2014), 261-266. 
KÁTAI-URBÁN Lajos: Analysis of the Legal and Institution-Building Experiences Related to...

[7] KÁTAI-URBÁN L., SZABÓ Á.: Veszélyes áru raktárlogisztika iparbiztonsági szabályozási környezetének értékelése. (Analyses of the legal regulation on industrial Safety used in Dangerous Goods Logistics.) Hadtudomány, XXIV 1 (2014), 115-125.

[8] KÁTAI-URBÁN L.: Veszélyes üzemekkel kapcsolatos iparbiztonsági jog-, intézmény és eszközrendszer fejlesztése Magyarországon. (Development of Legal, institution and Implementation System related to the Dangerous Establishments.) Budapest: Nemzeti Közszolgálati Egyetem, 2015.

[9] KÁTAI-URBÁN L.: Handbook for the Implementation of the Basic Tasks of the Hungarian Regulation on "Industrial Safety”. Budapest: Nemzeti Közszolgálati Egyetem, 2014.

[10] FERENCZ M., KÁTAI-URBÁN L., KÖRTVÉLYESSY Gy., NEMESKEY K., SÁROSI Gy., SULCZ Á., SZENTES E., VASS Gy.: Veszélyes áruk szállitása és tárolása. (Transportation and Storage of Dangerous Goods.) Budapest: Verlag Dashöfer Szakkiadó, 2010.

[11] SZAKÁL B., CIMER Zs., KÁTAI-URBÁN L., SÁROSI Gy., VASS Gy.: Iparbiztonság I.: Veszélyes anyagok és súlyos baleseteik az iparban és a közlekedésben. (Industrial Safety I.: Dangerous Substances and Accidents in the Industry and Transportation.) Budapest: SZIE Ybl Miklós Építéstudományi Kar, Tüzvédelmi és Biztonságtechnikai Intézet, 2012.

[12] BOGNÁR B., VASS Gy., KOZMA S.: A BM OKF Országos Iparbiztonsági Főfelügyelöség szakterületeinek bemutatása. (Introduction of the Professional Fields of National General Inspectorate for Industrial Safety.) $U_{j} j$ Magyar Közigazgatás, 56 (2012), 19-27.

[13] KÁTAI-URBÁN L., VASS Gy., LÉVAI Z., HOFFMANN I.: Iparbiztonság Magyarországon. (Industrial Safety in Hungary.) Védelem Online: Tüz- És Katasztrófavédelmi Szakkönyvtár, 221 (2015), 549.

[14] BLESZITY J., GRÓSZ Z., PÁNTYA P., KRIZSÁN Z.: A katasztrófavédelem szak oktatásának aktuális kérdései. (Actual Issues of Disaster Management Education.) Bolyai Szemle, 233 (2014), 7-13.

[15] BLESZITY J., GRÓSZ Z.: Egyetemi képzések a katasztrófavédelem számára. (University Education of Disaster Management.) Bolyai Szemle, 223 (2013), 9-16.

[16] ENDRÖDI I.: Polgári Védelmi Szakismeret 1. (Civil Protection Special Knowledge 1.) Budapest: Nemzeti Közszolgálati és Tankönyv Kiadó Zrt., 2015.

[17] ENDRÖDI I.: A katasztrófavédelem feladat- és szervezetrendszere. (Task and Organisational System of Disaster Management.) Budapest: Nemzeti Közszolgálati Egyetem Vezetö- és Továbbképzési Intézet, 2013. 